\title{
Suprasellar Germinoma
}

National Cancer Institute

\section{Source}

National Cancer Institute. Suprasellar Germinoma. NCI Thesaurus. Code C155803.

A germinoma that arises from the suprasellar region. 